\title{
A Rare Sugar, D-Allose, Confers Resistance to Rice Bacterial Blight with Upregulation of Defense-Related Genes in Oryza sativa
}

\author{
Akihito Kano, Kenji Gomi, Yumiko Yamasaki-Kokudo, Masaru Satoh, Takeshi Fukumoto, Kouhei Ohtani, Shigeyuki \\ Tajima, Ken Izumori, Keiji Tanaka, Yutaka Ishida, Yasuomi Tada, Yoko Nishizawa, and Kazuya Akimitsu
}

First, second, third, fifth, sixth, seventh, eighth, eleventh, and thirteenth authors: Faculty of Agriculture, Gene Research Center, and Rare Sugar Research Center, Kagawa University, Miki, Kagawa, 761-0795, Japan; fourth author: National Agricultural Research Center for Kyushu Okinawa Region (NARO), Koshi, Kumamoto, 861-1192, Japan; ninth author: Mitsui Chemicals Agro Co. Ltd., Yasu, Shiga, 5202342, Japan; tenth author: Shikoku Research Institute Inc., Yashima-nishi, Takamatsu, 761-0192, Japan; and twelfth author: National Institute of Agrobiological Sciences (NIAS), Tsukuba, 305-8602, Japan.

Accepted for publication 9 September 2009.

\begin{abstract}
Kano, A., Gomi, K., Yamasaki-Kokudo, Y., Satoh, M., Fukumoto, T., Ohtani, K., Tajima, S., Izumori, K., Tanaka, K., Ishida, Y., Tada, Y., Nishizawa, Y., and Akimitsu, K. 2010. A rare sugar, D-allose, confers resistance to rice bacterial blight with upregulation of defense-related genes in Oryza sativa. Phytopathology 100:85-90.
\end{abstract}

ABSTRACT

We investigated responses of rice plant to three rare sugars, D-altrose, D-sorbose, and D-allose, due to establishment of mass production methods for these rare sugars. Root growth and shoot growth were significantly inhibited by D-allose but not by the other rare sugars. A large-scale gene expression analysis using a rice microarray revealed that D-allose treatment causes a high upregulation of many defense-related, pathogenesisrelated (PR) protein genes in rice. The PR protein genes were not upregulated by other rare sugars. Furthermore, D-allose treatment of rice plants conferred limited resistance of the rice against the pathogen Xanthomonas oryzae pv. oryzae but the other tested sugars did not. These results indicate that D-allose has a growth inhibitory effect but might prove to be a candidate elicitor for reducing disease development in rice.

Additional keywords: induced resistance.
Plant cells respond to biotic or abiotic elicitors and induce various defense mechanisms. These responses include an accumulation of phytoalexins, a synthesis of pathogenesis-related (PR) proteins, and a production of reactive oxygen species (ROS) (25, 27,44). Biotic elicitors are derived from a component of pathogens such as fungal cell wall fragments or avirulence gene products. For example, one polysaccharide, chitin, the main component of cell walls in fungi, induces defense mechanisms in many plants (37). Yeast extract (YE) also induces several terpenoid biosynthetic genes and the generation of active oxygen species in cell suspensions of Catharanthus roseus (L.) G. Don (30), and the production of phytoalexins in Glycyrrhiza echinata L. (26). In recent years, the defense systems induced by these elicitors in plants have been found to be quite similar to the mammalian innate immunity networks in both the recognition of pathogen-associated molecular patterns (PAMPs) and the transduction of these signaling molecules (28).

In addition to biotic elicitors, abiotic elicitors such as copper chloride, dipotassium phosphate, and ferric chloride also induce plant defense responses. Dipotassium phosphate and ferric chloride induce resistance in rice against Magnaporthe grisea $(\mathrm{T}$. T. Hebert) M. E. Barr in the field (23). Benzothiadiazole (BTH) is an abiotic activator that protects various plants from diseases by activating the salicylic acid (SA) signaling pathway and inducing defense-related genes $(10,20,21,42)$. The discovery of biotic and

Corresponding author: K. Akimitsu; E-mail address: kazuya@ag.kagawa-u.ac.jp

* The $\boldsymbol{e}$-Xtra logo stands for "electronic extra" and indicates that the online version contains a table showing the D-allose responsive genes. Figure 6 appears in color online.

doi:10.1094/PHYTO-100-1-0085

(C) 2010 The American Phytopathological Society abiotic elicitors and their use on plants has been important in the development of our knowledge regarding plant basal resistance.

Studies of rare monosaccharides, sugars that are uncommon in nature $(11,15,16)$, have been limited by a lack of methods to produce these sugars in bulk. Recently, Izumori et al. $(15,16)$ developed a new technique for the bulk bioproduction of these rare sugars using recombinant enzymes from bacteria, facilitating studies for the effects of these rare sugars in animals, microbes, and plants. In animals, D-allose, one of the rare sugars, protected against an ischemic reperfusion injury in cirrhotic rat liver (12-14).

Although there are few studies on the effects of rare sugars on plants, one rare sugar, D-psicose, was reported to inhibit root elongation in lettuce (17) and to induce some defense-related genes in citrus (2). These results generated initial interests in the role of rare sugars that might have certain effects on growth inhibition or the induction of defense mechanisms in plants. Thus, as a first step toward understanding the effects of rare sugars on plants, we investigated the responses of rice to several rare sugars. Rice is one of the most important crops in the world, and genomewide studies such as microarrays are also applicable for this model plant. In this study, we show that one rare sugar, D-allose, effectively induces disease resistance with an upregulation of multiple plant defense-related PR protein genes against rice bacterial blight, a vascular wilt disease that is one of the most serious rice-plant diseases worldwide.

\section{MATERIALS AND METHODS}

Sugars. Rare sugars D-allose, D-altrose, and D-sorbose (Fig. 1), with respective purities of $100 \%$, were supplied by the Rare Sugar Research Center at Kagawa University. D-Glucose and D-fructose were purchased from Wako Pure Chemical Industries (Osaka, Japan). All sugars were dissolved in sterile water at various concentrations for the experiments. 
Plant materials, sugar treatments, and bacterial inoculation. Rice plants (Oryza sativa L. cv. Nipponbare) were grown to the two-leaf stage in a growth chamber in Kimura-B liquid medium (34) at $25^{\circ} \mathrm{C}$ ( $24 \mathrm{~h}$ of light) to examine the effects of the sugars on rice growth and gene expression analyses. Plants at the two-leaf stage were then incubated at $25^{\circ} \mathrm{C}$ in the medium amended with each sugar at final concentrations of 0.01 to $1 \mathrm{mM}$. After 2 days, the length of shoots and roots was measured or the seedlings were used for microarray and quantitative reversetranscription polymerase chain reaction (qRT-PCR) analyses.

Bacterial blight resistance was tested on rice plants at the sixleaf stage grown in potting soil (Iseki, Tokyo) at $25^{\circ} \mathrm{C}(14 \mathrm{~h}$ of light and $10 \mathrm{~h}$ of darkness) in black, soft plastic pots $(9 \mathrm{~cm}$ in diameter by $9 \mathrm{~cm}$ in height) with a small hole $(1 \mathrm{~cm}$ in diameter) at the bottom to absorb water from a tray $(20$ by 14 by $7 \mathrm{~cm}$ ) containing 1 liter of water. The six-leaf-stage rice plants were then placed on another tray (20 by 14 by $7 \mathrm{~cm}$ ) containing either 1 liter of water or water containing a sugar at a final concentration of 1,5 , or $10 \mathrm{mM}$. After 2 days, the potted plants were placed in another tray with water containing no sugar for subsequent inoculation of the fifth leaves with virulent Xanthomonas oryzae pv. oryzae and incubation at $25^{\circ} \mathrm{C}(14 \mathrm{~h}$ of light and $10 \mathrm{~h}$ of darkness) for 10 days. $X$. oryzae pv. oryzae strain $\mathrm{T} 7174$ race I was kindly provided by Dr. H. Kaku, National Institute of Agrobiological Sciences, and the bacterium was cultured on a nutrient agar (Becton, Dickinson \& Co., Spark, MD) slant containing $0.5 \%$ (wt/vol) sucrose at $25^{\circ} \mathrm{C}$ for $48 \mathrm{~h}$.

For the inoculation, a suspension of $X$. oryzae pv. oryzae cells was prepared by washing the bacterial cells from a slant culture with sterilized distilled water and adjusting the concentration to $\approx 1 \times 10^{6} \mathrm{CFU} \mathrm{m}{ }^{-1}$ in sterilized distilled water. The fully opened fifth leaf blades of the plants were inoculated using a clipping technique (18). The length of blight lesions on each leaf was then measured at 10 days after inoculation. Means of 12 replicates for each treatment were calculated with standard errors, and the statistical differences of respective data were determined by TukeyKramer test.

For examination of effects of D-allose treatment on $X$. oryzae pv. oryzae growth in the plant, the size of the $X$. oryzae pv. oryzae population in the leaf was estimated by grinding up the inoculated leaf blade and resuspending it in $10 \mathrm{ml}$ of sterile water to harvest the bacteria. The ground tissue extract was diluted and plated on a nutrient agar (add supplier) slant containing $0.5 \%$ (wt/vol) sucrose. After incubation of the slant at $25^{\circ} \mathrm{C}$ for 3 days, bacterial colonies were counted.

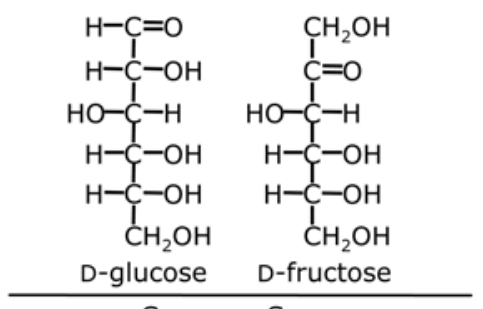

Common Sugars

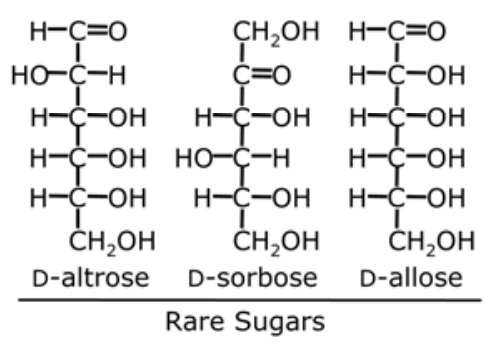

Fig. 1. Structures of the five monosaccharides (shown in Fisher projection) used in this study.
Microarray analysis. An Agilent Rice Oligo Microarray (44k, custom-made; Agilent Technologies, Redwood City, CA) was used for the microarray analysis. Seedlings of two-leaf-stage rice plants were cultured in Kimura-B liquid medium containing $0.5 \mathrm{mM}$ D-allose, $0.5 \mathrm{mM}$ D-glucose, or no sugar for 2 days. Total RNA was extracted from sugar-treated or mock-inoculated seedlings using an RNeasy Plant Mini Kit (Qiagen, Hilden, Germany). The RNAs (400 ng) were labeled with Cy-3 or Cy-5 using a Low RNA Input Linear Amplification/Labeling Kit (Agilent Technologies) according to the manufacturer's instructions, as were hybridization and wash processes. Hybridized microarrays were then scanned with an Agilent Microarray Scanner (Agilent Technologies). Feature Extraction Software (version 9.1; Agilent Technologies) was used to delineate and measure the signal intensity of each spot in the array and to normalize intensities. The background was measured around each spot as local background, calculated by the software. Statistical data extraction processes were performed based on three biological replicates for each treatment according to the instructions.

To identify genes up- or downregulated by treatments, we statistically analyzed the data using the National Institutes of Aging Array Analysis Tool (http://lgsun.grc.nia.nih.gov/ANOVA/) (36) and the most conservative error model (i.e., maximum of intensity-specific average error variance and actual error variance) to reduce false positives and the analysis of variance-false discovery rate (ANOVA-FDR, $q$-value) to $<0.05$. We extracted spots with changes in expression based on the criterion of a twofold increase or decrease at average levels of fold change. Fold changes in expression level in each treatment were compared with those of the respective mock controls. The microarray data files are deposited in the Gene Expression Omnibus Database (accession GSE15479). Sequence homologies of deduced amino acids from the cDNAs were determined using the TAIR database (http://www.Arabidopsis.org/). The genes were functionally classified according to their annotation either in the MIPS (http:// mips.gsf.de/proj/thal/db/index.html) or TAIR databases.

qRT-PCR. Total RNAs were extracted from rice seedlings as described for the microarray analysis, and the reverse transcription was performed using a Prime Script RT Reagent Kit (Takara, Shiga, Japan) according to the manufacturer's instructions. qRTPCR was run on a Thermal Cycler Dice TP800 System (Takara) using SYBR Premix Ex Taq Mixture (Takara) according to the manufacturer's instructions. The obtained data were analyzed according to the methods of De Vos et al. (6), with minor modifications. The transcript level of each gene was normalized by comparison to Actin (AK060893). Normalized transcript levels of the analyzed genes in each treatment were compared with those of the respective mocked controls, and the relative magnitude of the change in expression was calculated based on the data for three biological replicates for each treatment. Sequences of genespecific primers used for qRT-PCR are shown in Table 1. These primer sets were tested in a dissociation curve analysis and verified for the absence of nonspecific amplification.

\section{RESULTS}

Effects of rare sugars on rice growth. The schematic structures of the five monosaccharides used in this study are shown in Figure 1. To examine the effects of the rare sugars on rice growth, two aldose-type rare sugars, D-altrose and D-allose, and a ketose-type rare sugar, D-sorbose, were first tested in liquid medium at $0.5 \mathrm{mM}$ concentration. The effects of treatment with two common sugars, D-glucose and D-fructose, were also tested. There was no effect on rice growth, as determined by examining root and shoot lengths, after treatment of rice leaves with $\mathrm{D}$ glucose, D-altrose, D-fructose, or D-sorbose (Fig. 2A to C) compared with the control (no sugar added). In contrast, growth was inhibited by D-allose (Fig. 2A); mean length of shoots was $54 \pm$ 
$7 \%$ that of the control rice plants (Fig. 2B), and mean length of roots was $58 \pm 10 \%$ that of controls (Fig. 2C). This rice growth inhibition by D-allose treatment was further tested with other concentrations and reduction of shoot length was seen using concentrations $\geq 0.5 \mathrm{mM}$ (Fig. 2D) and reduction of root length was seen using concentrations $\geq 0.1 \mathrm{mM}$ (Fig. 2E).

Identification of $\mathrm{D}$-allose-responsive genes in rice. DNA microarray analysis was used to identify genes responsive to Dallose treatment in rice. We extracted total RNAs from the shoots of $0.5 \mathrm{mM}$ D-allose-, $0.5 \mathrm{mM}$ D-glucose-, or mock- (no sugar) treated rice plants at 2 days after treatment under the same conditions used for the growth test described above, and the gene expression patterns between D-allose- or D-glucose-treated and mock-treated rice plants were compared. Using statistical analysis (ANOVA-FDR, $q$-value < 0.05) $(3,36), 21,223$ spots for D-allose and 9,704 spots for D-glucose were extracted. We next extracted spots with changes in expression based on the criterion of a twofold increase or decrease in the average levels of change. Based on this criterion, D-allose upregulated the expression of 2,244 genes and downregulated the expression of 2,785 genes, whereas D-glucose upregulated the expression of 287 genes and downregulated the expression of 228 genes (Fig. 3). The expression of 211 genes was upregulated and that of 67 genes was downregulated in both treatments (Fig. 3). Among the upregulated genes, 2,033 were unique to $\mathrm{D}$-allose and 76 were unique to $\mathrm{D}$ glucose. Among the downregulated genes, 2,718 were unique to D-allose and 161 were unique to D-glucose (Fig. 3). To determine whether D-allose-treated rice regulated the expression of a particular class of genes, we classified genes highly responsive and unique to D-allose treatment-that is, those whose levels of change were either a fivefold increase or decrease-by their putative functions. In all, $\approx 32.0 \%$ (105) of the 328 D-allose-upregulated genes were defense-related genes (Fig. 4; supplementary table). In contrast, only $\approx 4.2 \%$ (7) of the 168 D-allose-downregulated genes were defense-related (Fig. 4; supplementary table). A list of representative defense-related genes upregulated more than fivefold by D-allose is shown in Table 2 .

Expression analysis of defense-related genes upregulated by D-allose after applying the other rare sugars. To analyze whether expression of the defense-related genes that were upregulated by D-allose is also upregulated by other rare sugars, we performed qRT-PCR using selected defense-related genes. We examined gene expression patterns of seven representative defenserelated genes: probenazole-inducible protein PBZ1 (AK071613), PR protein 1b PRIb (AK107926), proteinase inhibitor RBBI2-3 (AK064050), lipoxygenase RCI-1 (AK072241), peroxidase Pox22.3 (AK073202), $\beta$-1,3-glucanase (AK104862), and chitinase 1 (AK059767), which have been reported as upregulated genes after pathogen attack or treatment with a plant-defense activator $(1,5,8,24,31,33,35)$. All the tested defense-related genes were upregulated only by D-allose; the other sugars caused no significant change in the expression of these genes (Fig. 5), indicating that the upregulation of these defense-related genes is a D-allose-specific phenomenon among the tested rare, natural sugars in rice.
Effect of rare sugars on induction of disease resistance to rice bacterial blight. Upregulation of defense-related genes by Dallose led us to speculate that D-allose might confer resistance to rice pathogens. Thus, we performed a leaf inoculation test using
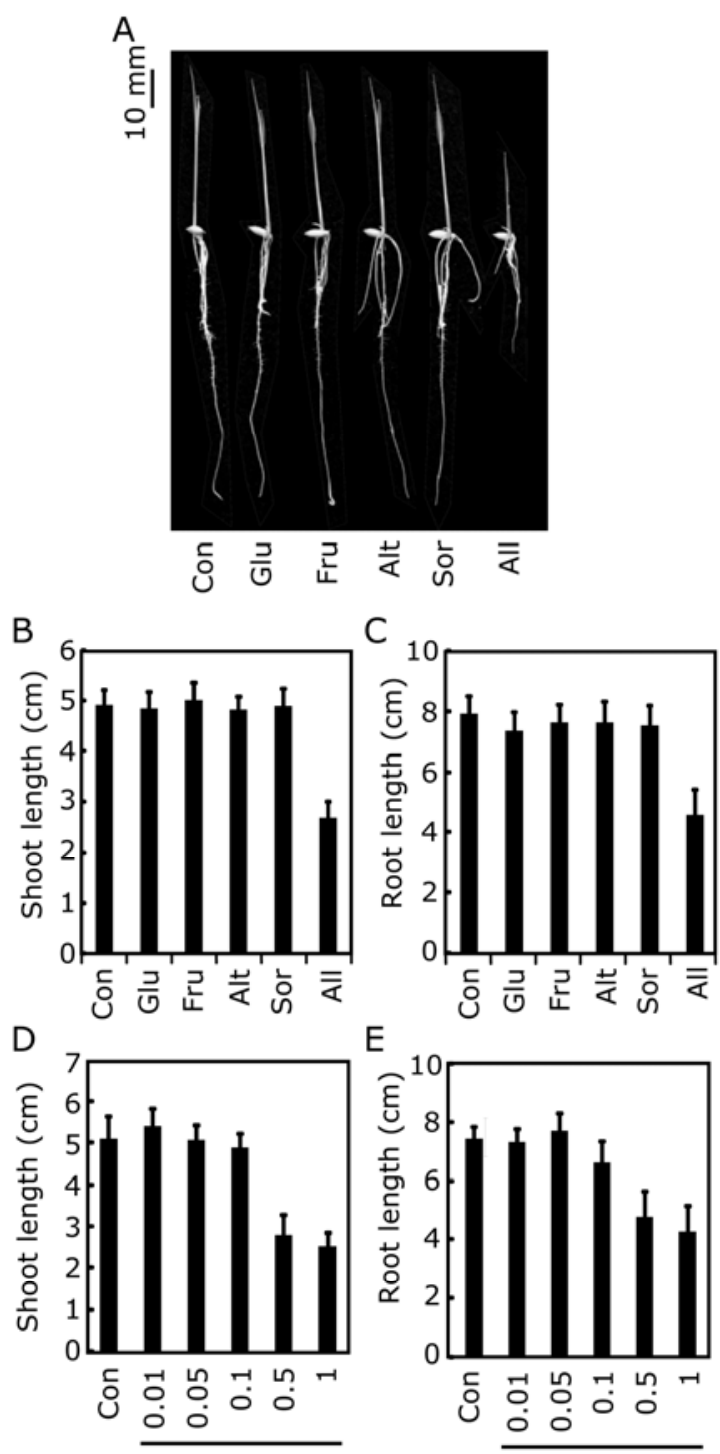

All (mM)

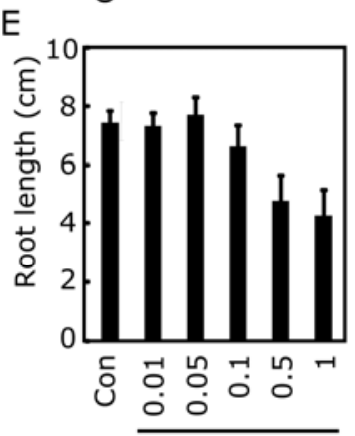

All (mM)

Fig. 2. Effects of sugar treatments on rice growth. A, Rice plants at 2 days after treatment with various sugars at $0.5 \mathrm{mM}$. Black bar indicates $10 \mathrm{~mm}$. Lengths of $\mathbf{B}$, shoots and $\mathbf{C}$, roots of rice after $0.5 \mathrm{mM}$ sugar treatments for 2 days. Values are means \pm standard deviation (SD) $(n=20)$. D and $\mathbf{E}$, Effects of D-allose treatment at different concentrations on rice growth. Lengths of $\mathbf{D}$, shoots and $\mathbf{E}$, roots of rice after treatment with 0.01, 0.05, 0.1, 0.5, and $1 \mathrm{mM}$ D-allose for 2 days. Values are means \pm SD $(n=10)$. Abbreviations: Con, control; Glu, D-glucose; Fru, D-fructose; Alt, D-altrose; Sor, D-sorbose; and All, D-allose.

TABLE 1. Sequences of gene-specific primers for rice pathogenesis-related protein genes used for quantitative reverse-transcription polymerase chain reaction

\begin{tabular}{|c|c|c|}
\hline Target gene ${ }^{\mathrm{a}}$ & Forward primer sequences $\left(5^{\prime}-3^{\prime}\right)$ & Reverse primer sequences $\left(5^{\prime}-3^{\prime}\right)$ \\
\hline$P B Z 1$ & GTGGTTGTGTTTATGTGCCTTTCTATG & ACTTGCCTCTCTTTATTCACCCATTG \\
\hline$P R 1 b$ & AGTGTCTGATCCACGCCTTC & ACCTGAAACAGAAAGAAACAGAGG \\
\hline$R B B I 2-3$ & CGTTCGTTCGATCATTCAGTGTTG & CACGTAATTAAGCTAAGCGAGTTGC \\
\hline$R C I-1$ & CCTCGTCAAGGAATGGCTAAC & AAAACAGTGGCAAACAGATGC \\
\hline POX22.3 & GGATGCGTTCGTTGCTGGAAG & CAACACCACCGTACCTATACTTGTG \\
\hline$\beta$-1,3-Glucanase & ACGAGACGGAGAGGCACTTC & TCGATCCCTTCTCAGAACAATCTTC \\
\hline Chitinase 1 & CAGCTACAAGTTTGAGTACGAGACC & GTATTATCACGACCGTTCGATGGAC \\
\hline Actin & GAGTATGATGAGTCGGGTCCAG & ACACCAACAATCCCAAACAGAG \\
\hline
\end{tabular}

a Accession number and full annotation of each target gene except Actin (AK060893) are in Table 2. 
the pathogen $X$. oryzae pv. oryzae. After a 2-day treatment of rice plants at the six-leaf stage with several concentrations of D-allose, the fifth leaf blades of the plants were inoculated with virulent $X$. oryzae pv. oryzae, and the length of blight lesions were measured 10 days later. The mean length of lesions was significantly shorter after treatments with D-allose $\geq 5 \mathrm{mM}$ (Fig. 6A). There was no effect on the length of lesions with treatment of $5 \mathrm{mM}$ D-glucose (Fig. 6B and D). At this growth stage, growth of rice plants was significantly inhibited by D-allose at $\geq 1 \mathrm{mM}$ (data not shown). The $X$. oryzae pv. oryzae population in $5 \mathrm{mM}$ D-allose-treated rice

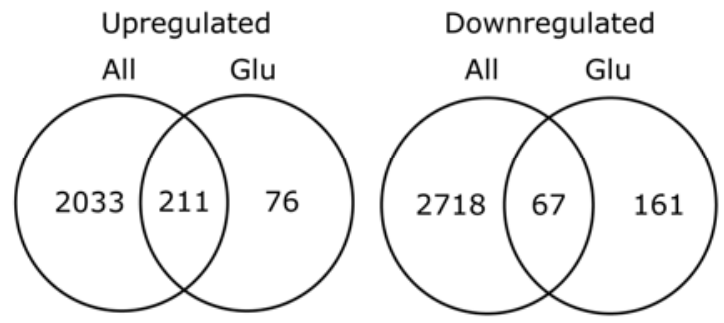

Fig. 3. Venn diagrams showing the numbers of overlapping and unique genes that were either upregulated or downregulated more than twofold by treatment with $0.5 \mathrm{mM}$ D-allose (All) or $0.5 \mathrm{mM}$ D-glucose (Glu) in rice.

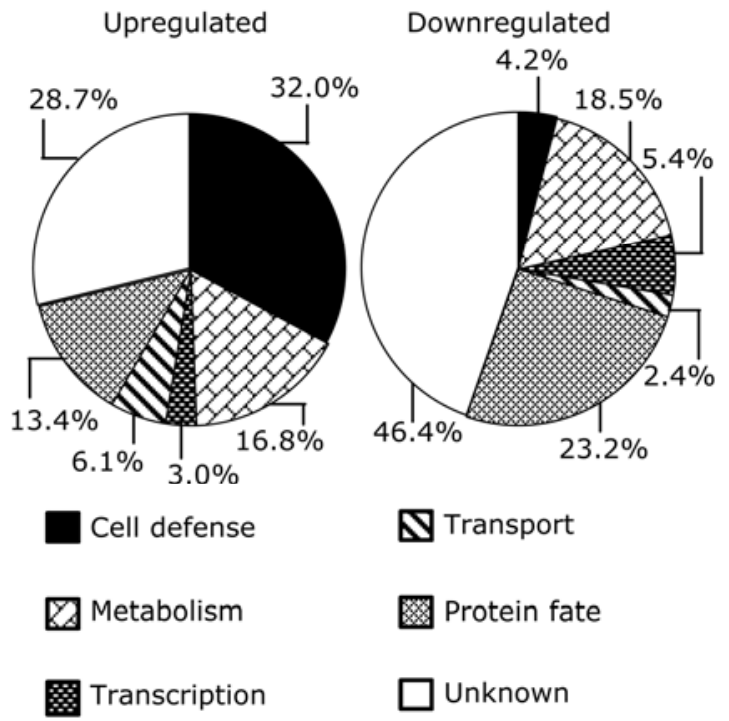

Fig. 4. Percentage of upregulated and downregulated genes in various functional categories after treatment with $0.5 \mathrm{mM}$ D-allose. Genes with expression that increased or decreased fivefold or more were classified by putative function according to their annotation in either the MIPS (http://mips.gsf.de/ proj/thal/db/index.html) or TAIR database (http://www.Arabidopsis.org/). at 10 days after inoculation was 25 -fold less than that in the control rice (Fig. 6C). There was no significant difference in the length of lesions caused by the other tested sugars and those on control plants (Fig. 6D).

\section{DISCUSSION}

A rare sugar, D-psicose, was reported to negatively affect root growth in lettuce (17). Likewise, among all tested rare sugars, Dallose inhibited root and shoot elongation of rice in this study,

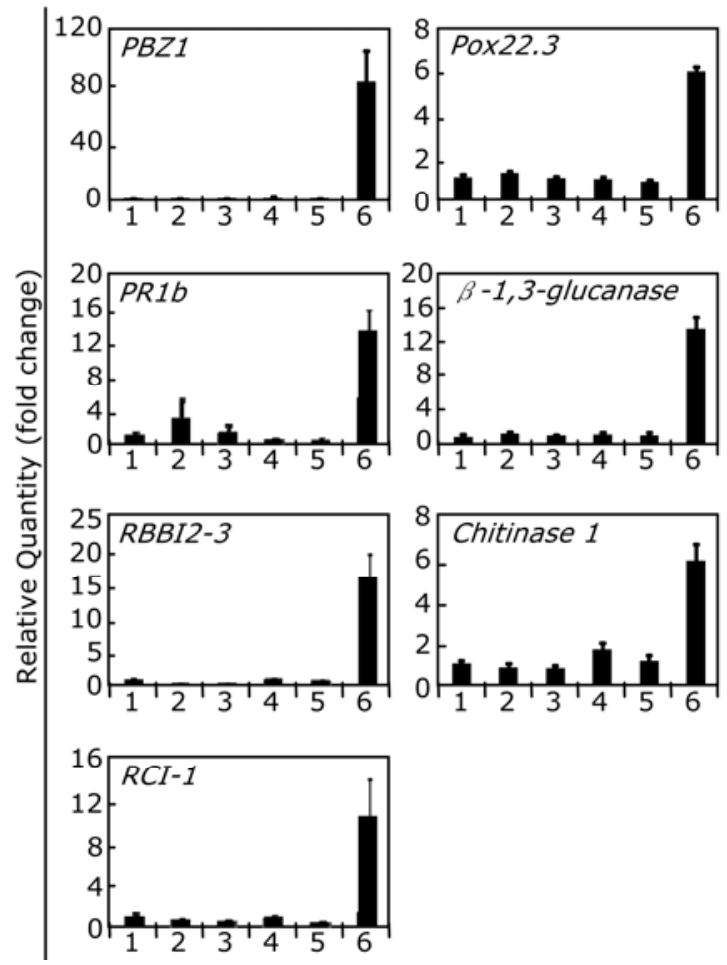

Fig. 5. Relative expression levels of selected D-allose-upregulated defenserelated genes after treatment with different types of sugars. Seedlings of twoleaf-stage rice plants were cultured in Kimura-B liquid medium containing $0.5 \mathrm{mM}$ sugars or no sugar (control) for 2 days. Total RNA was extracted from the seedlings and used for quantitative reverse-transcription polymerase chain reaction. The expression level for each gene was calculated relative to that in control plants. Control was set to 1 and a relative fold of increase was calculated. Data were normalized by using actin (AK060893) expression. Values are mean \pm standard deviation $(n=3)$. Lane 1, control; lane 2, D-glucose; lane 3, D-fructose; lane 4, D-altrose; lane 5, D-sorbose; and lane 6, D-allose. Accession number of each gene examined was PBZ1 (AK071613), PR1b (AK107926), RBBI2-3 (AK064050), RCI-1 (AK072241), Pox22.3 (AK073202), B-1,3-glucanase (AK104862), and Chitinase 1 (AK059767).

TABLE 2. Microarray data for the D-allose-upregulated defense genes of rice ${ }^{\mathrm{a}}$

\begin{tabular}{|c|c|c|c|c|}
\hline Accession & Annotation & Fold change & $q$-value & Reference \\
\hline AK071613 & Probenazole-inducible protein (PBZ1) & 75.13 & $<0.001$ & 24 \\
\hline X64396 & Lipoxygenase L-2 & 57.96 & $<0.001$ & 29 \\
\hline X68197 & Thaumatin-like protein & 14.68 & $<0.001$ & 32 \\
\hline AK107926 & Pathogenesis-related protein $1 \mathrm{~b}(\mathrm{PR} 1 \mathrm{~b})$ & 12.73 & $<0.001$ & 1 \\
\hline AK067834 & WRKY62 & 12.70 & $<0.001$ & 39 \\
\hline AK064050 & Bowman-Birk inhibitor (RBBI2-3) & 12.70 & $<0.001$ & 31 \\
\hline U77656 & Thaumatin-like protein & 7.54 & $<0.001$ & 9 \\
\hline AK070056 & $\beta-1,3$-Glucanase & 6.04 & $<0.001$ & 38 \\
\hline AK104862 & $\beta$-1,3-Glucanase & 5.43 & $<0.001$ & 8 \\
\hline AK108376 & Glutathione $S$-transferase & 5.37 & $<0.001$ & 38 \\
\hline AK059767 & Chitinase 1 & 5.23 & $<0.001$ & 33 \\
\hline
\end{tabular}

a This is a partial list of genes (14 of 105) upregulated more than fivefold by D-allose; their roles in rice resistance were clarified in references. 
suggesting that some rare sugars significantly affect plant growth. In our microarray analysis, we found that D-allose induces a change in the expression of many genes, including highly upregulating defense-related genes.

Growth defects are frequently observed in constitutive defenseresponse mutants of rice and transgenic rice plants overexpressing defense-related genes $(4,7,22,39-41,45)$. Therefore, the same types of linkage between growth inhibition and defense induction may explain the high upregulation of defense-related genes by D-allose coupled with an inhibitory effect on rice growth. Another possibility is that some transcription factors affected by D-allose might regulate both the transduction of particular signals involved in rice growth and the upregulation of defense-related genes. We identified multiple genes encoding transcription factors that were up- or downregulated by D-allose treatment in the microarray analysis. Further studies of these gene-regulatory genes might provide ideas to explain the mechanisms underlying these Dallose effects on rice.

The upregulation of PR genes is one of the best characterized defense responses against pathogen attacks in many plant species (43). PBZ1, POX22.3, and Chitinase 1 are PR protein genes that are upregulated in rice after inoculation with the bacterial pathogen $X$. oryzae pv. oryzae or the fungal pathogen $M$. grisea $(5,19,24)$. Inhibition of protease activity by a protease inhibitor in rice might prevent growth of $X$. oryzae pv. oryzae because populations of protease-defective mutants of $X$. oryzae pv. oryzae were 10- to 100-fold smaller than those of the wild-type strain in rice plants (46). Therefore, the upregulation of a proteinase inhibitor
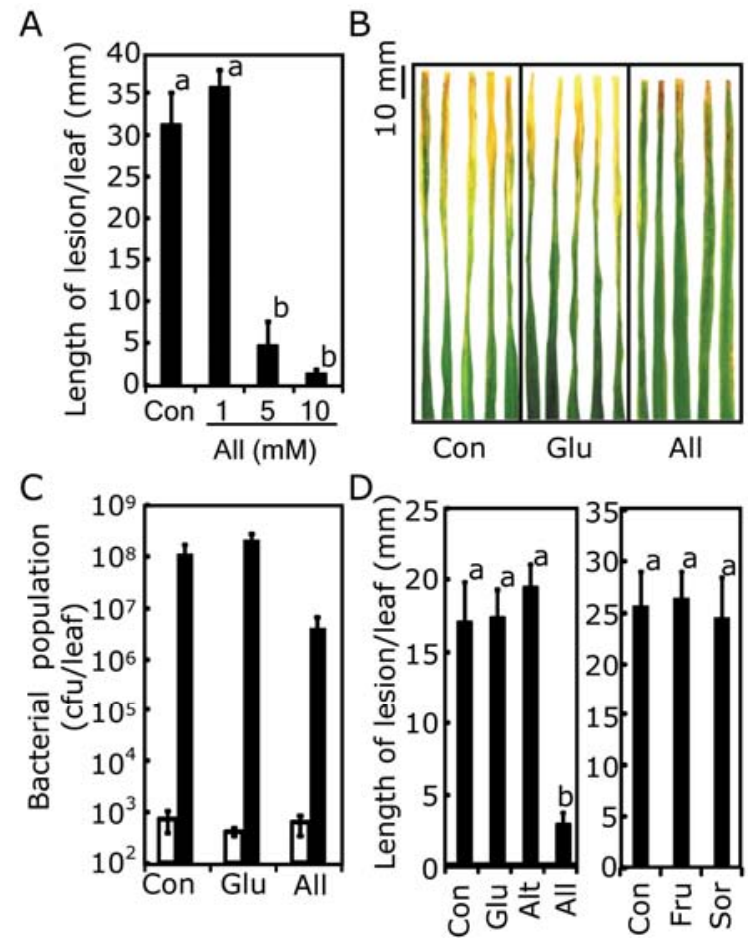

Fig. 6. Effects of pretreatment with D-allose or other sugars on resistance of rice to bacterial blight 10 days after inoculation with Xanthomonas oryzae pv. oryzae. A, Length of lesions on fifth leaf blades 10 days after inoculation with $X$. oryzae pv. oryzae. Values are means \pm standard error $(\mathrm{SE})(n=12)$. Means accompanied by different letters are significantly different at $P<0.05$ (TukeyKramer test). B, Leaf blades showing symptoms and lesions of bacterial blight developed after pretreatment with $5 \mathrm{mM}$ sugars. C, Bacterial populations in inoculated leaf blades at $0(\square)$ and $10(\boldsymbol{\square})$ days after pretreatment with $5 \mathrm{mM}$ sugar treatments. Values are means $\pm \operatorname{SE}(n=4)$. D, Lesion length on leaf blades pretreated with $5 \mathrm{mM}$ sugars. Length of lesions was measured 10 days after inoculation. Values are means $\pm \mathrm{SE}(n=12)$. Means accompanied by different letters are significantly different at $P<0.05$ (Tukey-Kramer test). Abbreviations: Con, control; Glu, D-glucose; Fru, D-fructose; Alt, D-altrose; Sor, D-sorbose; and All, D-allose. gene, $R B B I 2-3$, might have an important role in the D-alloseinduced resistance against $X$. oryzae pv. oryzae. From these results, we can suggest that the D-allose-induced resistance against $X$. oryzae pv. oryzae is due, at least partly, to the coordinate expression of PR genes and that this resistance against $X$. oryzae pv. oryzae and expression of PR protein genes are induced only by D-allose but not by other rare sugars used in this study.

In addition to conferring resistance to $X$. oryzae pv. oryzae, Dallose might also confer resistance to rice blast caused by $M$. grisea. Transgenic rice plants overexpressing $R B B I 2-3$ were highly resistant to $M$. grisea (31) and a lipoxygenase gene, $R C I-1$, was upregulated by a chemical inducer of acquired resistance to $M$. grisea (35). $\beta$-1,3-Glucanase and chitinase have well-recognized antifungal activity due to their hydrolytic action on cell walls (43). These results suggest that D-allose may also confer resistance to $M$. grisea, but further studies are necessary to clarify the signal transduction pathway responsible for the resistance against M. grisea in D-allose-treated rice.

Our findings indicate that the rare sugar D-allose causes physiological changes in rice and actively induces disease resistance. As far as we know, this is the first report characterizing plant responses to a rare sugar and the subsequent induction of plant defense. It is not yet clear how these distinctive responses, such as upregulation of defense-related genes and growth inhibition, are triggered by D-allose. However, the genes identified here could provide new information on the mechanism of this induced resistance. Further studies are necessary to understand entirely the mechanisms behind the resistance induced by D-allose. However, some of the rare sugars, including $\mathrm{D}$-allose, might be candidate agents to test for reduction of disease development in rice.

\section{ACKNOWLEDGMENTS}

A. Kano and K. Gomi contributed equally to this work. We thank $\mathrm{H}$. Kaku, National Institute of Agrobiological Sciences (NIAS), Tsukuba, Japan, for providing rice seeds and X. oryzae pv. oryzae; H. Gomi for technical assistance; and the Rice Genome Resource Center at NIAS for the use of the rice microarray analysis system. This work was supported by the Program for Promotion of Basic Research Activities for Innovative Biosciences (PROBRAIN).

\section{LITERATURE CITED}

1. Agrawal, G. K., Rakwal, R., and Jwa, N. S. 2000. Rice (Oryza sativa L.) OsPR $1 b$ gene is phytohormonally regulated in close interaction with light signals. Biochem. Biophys. Res. Commun. 278:290-298.

2. Akimitsu, K., Tsukuda, S., Suzuku, N., Ichii, M., and Tajima, S. 2005. An elicitor effect of D-psicose for induction of plant defense gene transcriptions. Pages 163-168 in: International Society of Rare Sugars, Kagawa, Japan.

3. Benjamini, Y., and Hochberg, Y. 1995. Controlling the false discovery rate: A practical and powerful approach to multiple testing. J. R. Stat. Soc. B. 57:289-300.

4. Chern, M., Fitzgerald, H. A., Canlas, P. E., Navarre, D. A., and Ronald, P. C. 2005. Overexpression of a rice NPR1 homolog leads to constitutive activation of defense response and hypersensitivity to light. Mol. PlantMicrobe Interact. 18:511-520.

5. Chittoor, J. M., Leach, J. E., and White, F. F. 1997. Differential induction of a peroxidase gene family during infection of rice by Xanthomonas oryzae pv. oryzae. Mol. Plant-Microbe Interact. 10:861-871.

6. De Vos, M., Van Oosten, V. R., Van Poecke, R. M. P., Van Pelt, J. A., Pozo, M. J., Mueller, M. J., Buchala, A. J., Metraux, J. P., Van Loon, L. C., Dicke, M., and Pieterse, C. M. J. 2005. Signal signature and transcriptome changes of Arabidopsis during pathogen and insect attack. Mol. Plant-Microbe Interact. 18:923-937.

7. Ding, X., Cao, Y., Huang, L., Zhao, J., Xu, C., Li, X., and Wang, S. 2008. Activation of the indole-3-acetic acid amido synthetase GH3-8 suppresses expansin expression and promotes salicylate- and jasmonate-independent basal immunity in rice. Plant Cell 20:228-240.

8. Faivre-Rampant, O., Thomas, J., Allegre, M., Morel, J. B., Tharreau, D., Notteghem, J. L., Lebrun, M. H., Schaffrath, U., and Piffanelli, P. 2008. Characterization of the model system rice-Magnaporthe for the study of nonhost resistance in cereals. New Phytol. 180:899-910. 
9. Gomez-Ariza, J., Campo, S., Rufat, M., Estopa, M., Messequer, J., Sequndo. B. S., and Coca, M. 2007. Sucrose-mediated priming of plant defense responses and broad-spectrum disease resistance by overexpression of the maize pathogenesis-related PRms proteins in rice plant. Mol. Plant-Microbe Interact. 20:832-842.

10. Gorlach, J., Volrath, S., Knauf-Beiter, G., Hengy, G., Beckhove, U., Kogel, K. H., Oostendorp, M., Staub, T., Ward, E., Kessmann, H., and Ryals, J. 1996. Benzothiadiazole, a nove1 class of inducers of systemic acquired resistance, activates gene expression and disease resistance in wheat. Plant Cell 8:629-643.

11. Granstroem, T. B., Takada, G., Tokuda, M., and Izumori, K. 2004. Review Izumoring: a novel and complete strategy for bioproduction of rare sugars. J. Biosci. Bioeng. 2:89-94.

12. Hossain, M. A., Izuishi, K., and Maeta, H. 2003. Protective effects of Dallose against ischemia reperfusion injury of the liver. J. Hepatobiliary Pancreat. Surg. 10:218-225.

13. Hossain, M. A., Wakabayashi, H., Goda, F., Kobayashi, S., Maeba, T., and Maeta, H. 2000. Effect of immunosuppressants FK506 and D-allose on allogenic orthotopic liver transplantation in rats. Transplant. Proc. 32:2021-2023.

14. Hossain, M. A., Wakabayashi, H., Izuishi, K., Okano, K., Yachida, S., Tokuda, S., Izuishi, K., and Maeta, H. 2006. Improved microcirculatory effect of D-allose on hepatic ischemia reperfusion following partial hepatectomy in cirrhotic rat liver. J. Biosci. Bioeng. 101:369-371.

15. Izumori, K. 2002. Bioproduction strategies for rare hexose sugars. Naturwissenschaften 89:120-124.

16. Izumori, K. 2006. Izumoring: a strategy for bioproduction of all hexoses. J. Biotechnol. 124:717-722.

17. Kato-Noguchi, H., Takaoka, T., and Izumori, K. 2005. Psicose inhibits lettuce root growth via a hexokinase-independent pathway. Physiol. Plant. 125:293-298.

18. Kauffman, H. E., Reddy, A. P. K., Hsien, S. P. Y., and Merca, S. D. 1973. An improved technique for evaluating resistance of rice varieties to Xanthomonas oryzae. Plant Dis. Rep. 57:537-541.

19. Kim, S., Ahn, I.-P., and Lee, Y.-H. 2001. Analysis of genes expressed during rice-Magnaporthe grisea interactions. Mol. Plant-Microbe Interact. 14:1340-1346.

20. Kohler, A., Schwindling, S., and Conrath, U. 2002. Benzothiadiazole induced priming for potentiated responses to pathogen infection, wounding, and infiltration of water into leaves requires the NPR1/NIM1 gene in Arabidopsis. Plant Physiol. 128:1046-1056.

21. Lawton, K., Friedrich, L., Hunt, M., Weymann, K., Staub, T., Kessmann, H., and Ryals, J. 1996. Benzothiadiazole induces disease resistance in Arabidopsis by activation of the systemic acquired resistance signal transduction pathway. Plant J. 10:71-82.

22. Liu, X. Q., Bai, X. Q., Qian, Q., Wang, X. J., Chen, M. S., and Chu, C. C. 2005. OsWRKY03, a rice transcriptional activator that functions in defense signaling pathway upstream of OsNPR1. Cell Res. 15:593-603.

23. Manandhar, H. K., Lyngs Jorgensen, H. J., Mathur, S. B., and SmedegaardPetersen, V. 1998. Resistance to rice blast induced by ferric chloride, dipotassium hydrogen phosphate and salicylic acid. Crop Prot. 17:323-329.

24. Midoh, N., and Iwata, M. 1996. Cloning and characterization of a probenazole-inducible gene for an intracellular pathogenesis-related protein in rice. Plant Cell Physiol. 37:9-18.

25. Mittler, R., Vanderauwera, S., Gollery, M., and Van Breusegem, F. 2004. Reactive oxygen gene network of plants. Trends Plant Sci. 9:490-498.

26. Nakamura, K., Akashi, T., Aoki, T., Kawaguchi, K., and Ayabe, S. 1999. Induction of isoflavonoid and retrochalcone branches of the flavonoid pathway in cultured Glycyrrhiza echinata cells treated with yeast extract. Biosci. Biotechnol. Biochem. 63:1618-1620.

27. Nicholson, R. L., and Hammerschmidt. R. 1992. Phenolic compounds and their role in disease resistance. Annu. Rev. Phytopathol. 30:369-386.
28. Nürnberger, T., Brunner, F., Kemmerling, B., and Piater, L. 2004. Innate immunity in plants and animals: striking similarities and obvious differences. Immunol. Rev. 198:249-266.

29. Ohta, H., Shirano, Y., Tanaka, K., Morlta, Y., and Shibata, D. 1992. cDNA cloning of rice lipoxygenase L-2 and characterization using active enzyme expressed from the cDNA in Escherichia coli. Eur. J. Biochem. 206:331-336.

30. Pauw, B., van Duijn, B., Kijne, J. W., and Memelink, J. 2004. Activation of the oxidative burst by yeast elicitor in Catharanthus roseus cells occurs independently of the activation of genes involved in alkaloid biosynthesis. Plant Mol. Biol. 55:797-805.

31. Qu, L. J., Chen, J., Liu, M., Pan, N., Okamoto, H., Lin, Z., Li, C., Li, D., Wang, J., Zhu, G., Zhao, X., Chen, X., Gu, H., and Chen, Z. 2003. Molecular cloning and functional analysis of a novel type of BowmanBirk inhibitor gene family in rice. Plant Physiol. 133:560-570.

32. Reimmann, C., and Dudler, R. 1993. cDNA cloning and sequence analysis of a pathogen-induced thaumatin-like protein from rice (Oryza satiua). Plant Physiol. 101:1113-1114.

33. Sahi, C., Singh, A., Kumar, K., Blumwald, E., and Grover, A. 2006. Salt stress response in rice: Genetics, molecular biology, and comparative genomics. Funct. Integr. Genomics 6:263-284.

34. Sato, H., Imiya, Y., Ida, S., and Ichii, M. 1996. Characterization of molybdenum cofactor mutant of rice, Oryza sativa L. Plant Sci. 119:3947.

35. Schaffrath, U., Zabbai, F., and Dudler, R. 2000. Characterization of RCI1 , a chloroplastic rice lipoxygenase whose synthesis is induced by chemical plant resistance activators. Eur. J. Biochem. 267:5935-5942.

36. Sharov, A. A., Dudekula, D. B., and Ko, M. S. H. 2005. A web-based tool for principal component and significance analysis of microarray data. Bioinformatics 21:2548-2549.

37. Shibuya, N., and Minami, E. 2001. Oligosaccharide signaling for defense responses in plants. Physiol. Mol. Plant Pathol. 59:223-233.

38. Shimizu, T., Satoh, K., Kikuchi, S., and Omura, T. The repression of cell wall- and plastid-related genes and the induction of defense-related genes in rice plants infected with Rice dwarf virus. Mol. Plant-Microbe Interact. $3: 247-254$

39. Shimono, M., Sugano, S., Nakayama, A., Jiang, C. J., Ono, K., Toki, S., and Takatsuji, H. 2007. Rice WRKY45 plays a crucial role in benzothiadiazole-inducible blast resistance. Plant Cell 19:2064-2076.

40. Takahashi, A., Agrawal, G. K., Yamazaki, M., Onosato, K., Miyao, A., Kawasaki, T., Shimamoto, K., and Hirochika, H. 2007. Rice Ptila negatively regulates RAR1-dependent defense responses. Plant Cell 9:29402951.

41. Takahashi, A., Kawasaki, T., Henmi, K., Shii, K., Kodama, O., Satoh, H., and Shimamoto, K. 1999. Lesion mimic mutants of rice with alterations in early signaling events of defense. Plant J. 17:535-545.

42. Van Hulten, M., M. Pelser, L. C. Van Loon, C. M. J. Pieterse, and Ton, J. 2006. Costs and benefits of priming for defense in Arabidopsis. Proc. Natl. Acad. Sci. USA 103:5602-5607.

43. Van Loon, L. C., Rep, M., and Pieterse, C. M. J. 2006. Significance of inducible defense-related proteins in infected plants. Annu. Rev. Phytopathol. 44:135-162.

44. Van Loon, L. C., and Van Strien, E. A. 1999. The families of pathogenesis-related proteins, their activities, and comparative analysis of PR-1 type proteins. Physiol. Mol. Plant Pathol. 55:85-97.

45. Wang, H. H., Hao, J. J., Chen, X. J., Hao, Z. N., Wang, X., Lou, Y. G., Peng, Y. L., and Guo, Z. J. 2007. Overexpression of rice WRKY89 enhances ultraviolet $\mathrm{B}$ tolerance and disease resistance in rice plants. Plant Mol. Biol. 65:799-815.

46. Xu, G. W., and Gonzales, C. F. 1987. Evaluation of TN4431-induced protease mutants of Xanthomonas campestris pv. oryzae for growth in plants and pathogenicity. Phytopathology 79:1210-1215. 